\title{
The Perception of the Legitimacy of Citizens' Assemblies in Deeply Divided Places? Evidence of Public and Elite Opinion from Consociational Northern Ireland
}

\author{
John Garry ${ }^{1 \star}$ (D), James Pow $^{2}$ (D), John Coakley ${ }^{3}$ (D), David Farrell ${ }^{4}$ (D), Brendan O’Leary ${ }^{5}$ (iD \\ and James Tilley ${ }^{6}$ (D) \\ ${ }^{1}$ Department of Politics, Queen's University Belfast, Belfast, UK, ${ }^{2}$ Department of Politics, Queen's \\ University Belfast, Belfast, UK, ${ }^{3}$ Department of Politics, Queen's University Belfast, Belfast, UK, \\ ${ }^{4}$ Department of Politics, University College Dublin, Dublin, Ireland, ${ }^{5}$ Department of Political Science, \\ University of Pennsylvania, Philadelphia, US, and Department of Politics, Queen's University Belfast, \\ Belfast, UK, and ${ }^{6}$ Department of Politics and International Relations, University of Oxford, Oxford, UK \\ ${ }^{\star}$ Corresponding author. Email: j.garry@qub.ac.uk
}

(Received 1 May 2020; revised 15 December 2020; accepted 15 January 2021; first published online 26 March 2021)

\begin{abstract}
How much public and elite support is there for the use of a citizens' assembly - a random selection of citizens brought together to consider a policy issue - to tackle major, deadlock-inducing disagreements in deeply divided places with consociational political institutions? We focus on Northern Ireland and use evidence from a cross-sectional attitude survey, a survey-based experiment and elite interviews. We find that the general public support decision-making by a citizens' assembly, even when the decision reached is one they personally disagree with. However, support is lower among those with strong ideological views. We also find that elected politicians oppose delegating decision-making power to an 'undemocratic' citizens' assembly, but are more supportive of recommendation-making power. These findings highlight the potential for post-conflict consociations to be amended, with the consent of the parties, to include citizens' assemblies that make recommendations but not binding policy.
\end{abstract}

Keywords: citizens' assemblies; mini-publics; consociations; public and elite opinion; deeply divided places

A citizens' assembly is a random selection of ordinary citizens who are brought together to consider a policy issue. Through a structured process of learning, deliberation and voting, citizens' assemblies help inform public policy by offering recommendations which can then be considered by government or put to a referendum of the general population (Smith 2009). Citizens' assemblies have

(C) The Author(s), 2021. Published by Cambridge University Press on behalf of Government and Opposition Limited. This is an Open Access article, distributed under the terms of the Creative Commons Attribution licence (http://creativecommons.org/licenses/by/4.0/), which permits unrestricted re-use, distribution, and reproduction in any medium, provided the original work is properly cited. 
been formally established to supplement representative institutions in a variety of contexts, dealing with issues ranging from electoral reform in Canada and the Netherlands (Fournier et al. 2011) to same-sex marriage and abortion law in the Republic of Ireland (Farrell et al. 2019). For deliberative democrats, the use of citizens' assemblies and other types of mini-publics helps to promote a more authentic democracy, emphasizing careful consideration by citizens as an integral feature of legitimate decision-making (Dryzek et al. 2019; Fishkin 2009). Slightly less abstractly, advocates argue that a practical advantage of citizens' assemblies is their potential to help address important or intractable problems that elected bodies have been unable or unwilling to address on their own (Warren 2008).

Most research to date has focused on citizens' assemblies as democratic vehicles to make recommendations rather than binding policy decisions. While some normative scholars do advocate strong policymaking powers for citizens' assemblies (Gastil and Wright 2019; Hennig 2017; Vandamme et al. 2018; Van Reybrouck 2014), critics, in contrast, highlight the legitimacy problems that may result from such delegation. According to Carolina Johnson and John Gastil (2015: 4), deliberation 'may produce decisions considered legitimate within the body that deliberated ... but these deliberative decisions are not necessarily legitimate as binding decisions over a wider democratic polity' (see also Mackenzie and Warren 2012; Mansbridge 2007).

In this article, we address directly the question of the legitimacy of binding decision-making by a citizens' assembly, focusing on the extent to which the general public perceive such decision-making as legitimate. We build upon a number of recent studies which have empirically examined public support for binding decision-making by citizens' assemblies - in France (Bedock and Pilet 2020a), Belgium (Bedock and Pilet 2020b) and the US (Rojon et al. 2019). We focus on the application of a citizens' assembly in a deeply divided context, and specifically a post-conflict consociational power-sharing context. Consociation is a democratic design that seeks to facilitate peaceful politics in places that have been riven by conflict (McGarry and O'Leary 2009; O'Leary 2020: 1-32). Although advantageous in many regards, the group veto rights integral to consociational power-sharing arrangements generate the potential for policy gridlock to emerge, and this can threaten the stability of the system. In such a context, we argue that it is valuable to consider how the political arrangements may be complemented by agreed additional mechanisms - such as citizens' assemblies - to overcome policy gridlock, when it occurs, by making binding decisions.

In addition to assessing the public's perceptions of legitimacy, we also systematically examine the extent to which elected politicians perceive policymaking citizens' assemblies as legitimate. Perhaps unsurprisingly, existing research has found that political elites tend to be somewhat negatively disposed to citizens' assemblies: expressing either conditional support (Niessen 2019) or scepticism (Carson and Schecter 2019). Thus, we can expect that politicians are likely to be particularly reluctant to delegate decision-making power to a citizens' assembly. However, we currently have little systematic evidence on exactly what features of citizens' assemblies are regarded as most problematic by elites, and under what circumstances - if any - elites may potentially support assigning them significant powers.

Taken together, these observations motivate our present research question: How much public and elite support is there for the use of citizens' assemblies to make 
binding decisions on the major, deadlock-inducing disagreements in deeply divided places with consociational political institutions? We focus on Northern Ireland and use a combination of evidence from a cross-sectional attitude survey, a survey-based experiment and elite interviews. We find that the general public support decisionmaking by a citizens' assembly, even when they personally disagree with the decision reached. However, support is lower among those with strong ideological views than among moderates. We also find that elites are hostile to delegating decision-making power, primarily because they regard democracy as synonymous with elections. They are, however, more positively disposed to delegating recommendation-making power.

The remainder of our article is organized as follows. After elaborating our expectations, we report the findings of our three distinct empirical studies and then discuss the implications for deeply divided consociational systems such as Northern Ireland.

\section{Expectations}

Political systems have three elements: inputs, throughputs and outputs (Easton 1965). In a consociational power-sharing system, decision-makers are chosen at the input stage by election under a proportional representation voting system (see Table 1). In such elections, voters within each ethno-national (or other type of) group are incentivized to vote for the particular party in their electoral bloc which, because of its history and reputation as a hard-line party, is best-placed to robustly defend group interests in the consociational power-sharing executive. ${ }^{1}$ Indeed, even moderate voters engage in 'compensational voting' in anticipation of post-election bargaining: 'voters will want to be represented by their "strongest voice"' (Mitchell and Evans 2009: 152). This 'tribune' voting leads to a decline in representation of the traditionally moderate party and a rise in representation of the staunchest ethno-national party in the relevant bloc (Mitchell et al. 2009). At the throughput stage, the decision-making process in consociations is characterized by bargaining between elites, rather than by debate and deliberation (Hayward 2014; Steiner 2012). Regarding decision rules at the output stage, consociational power-sharing incorporates veto rights to protect group interests against possible discrimination, leading to gridlock if veto rights are frequently exercised (and abused) (McCulloch 2014).

Gridlock is a particularly pressing problem in Northern Ireland's consociational system. The 'tribune' parties from each bloc - Sinn Féin as the staunch advocate of Irish nationalists and the Democratic Unionist Party (DUP) as the firm defender of British unionists - have clashed repeatedly, with disagreements over same-sex marriage, welfare reform, legacy questions related to the conflict, and the symbolic and cultural politics of flag display, parades and legislation on the Irish language. Faced with such stalemate in a consociational power-sharing system, a range of institutional responses are possible. First, there may be an attempt to persevere with the system in its existing form. For example, emergency cross-party talks, which in the Northern Ireland context are usually chaired by the British government, or an international diplomat, may be convened to try and resolve the parties' differences. These elite-level talks take place behind closed doors and usually take 
Table 1. Consociation's Limitations, the Potential Remedial Value of Citizens' Assemblies and Hypothesized Citizen Support Base

\begin{tabular}{|c|c|c|c|}
\hline & \multicolumn{3}{|c|}{ Stage of decision-making process } \\
\hline & Input $\rightarrow$ & Throughput $\rightarrow$ & Output \\
\hline & $\begin{array}{c}\text { Selection of } \\
\text { decision-makers }\end{array}$ & $\begin{array}{l}\text { Decision-making } \\
\text { process }\end{array}$ & Decision rules \\
\hline $\begin{array}{l}\text { Consociational } \\
\text { feature }\end{array}$ & $\begin{array}{l}\text { Election under } \\
\text { proportional } \\
\text { electoral system }\end{array}$ & Elite bargaining & Mutual vetoes \\
\hline Potential problem? & $\begin{array}{l}\text { Under-representation } \\
\text { of traditionally } \\
\text { moderate views due } \\
\text { to 'tribune' voting }\end{array}$ & Lack of deliberation & Gridlock \\
\hline $\begin{array}{l}\text { Citizens' assembly } \\
\text { feature }\end{array}$ & Random selection & $\begin{array}{l}\text { Deliberation among } \\
\text { citizens }\end{array}$ & $\begin{array}{l}\text { Collective decision } \\
\text { by majority rule }\end{array}$ \\
\hline Potential value? & More inclusive & $\begin{array}{l}\text { Less partisan and } \\
\text { more deliberative }\end{array}$ & More decisive \\
\hline $\begin{array}{l}\text { Type of citizen } \\
\text { likely to support } \\
\text { citizens' assembly }\end{array}$ & Political moderates & Non-partisans & $\begin{array}{l}\text { Citizens who trust } \\
\text { the out-group }\end{array}$ \\
\hline
\end{tabular}

months to produce a result, if they do so at all. ${ }^{2}$ Alternatively, a fresh election may be called in an attempt to establish fresh mandates. Perhaps electoral losses will be suffered either by the party favouring the status quo (through its use of veto) or by the party insisting on policy change. Perhaps also an election may prompt compromise by both sides, although if interparty dispute is acrimonious before an election, concessions during or directly after an election campaign may be difficult to achieve.

A second, very different, approach is to suspend consociation, either for a fixed period or indefinitely. In the Northern Ireland context, that has involved direct rule from Westminster (tempered by consultation with Ireland in the British-Irish Intergovernmental Conference as established in the 1998 Belfast Agreement). This course of action may provide a breathing space, but is not necessarily productive or sustainable, as the major political parties in Great Britain - and in Ireland insist that Northern Ireland should retain its autonomous Assembly.

A third approach is to supplement the existing system with some form of citizenbased democratic decision-making. From a direct democracy perspective, a referendum could present voters with a proposition on the gridlock-inducing contentious issue, and they could express a view. Such an option could be decisive. However, it could also be divisive as an intensive campaign, centred on the antagonistic views of the main competing tribune parties (Sinn Féin and the DUP), would likely occur, exacerbated by the referendum device being viewed by many as an overly crude majoritarian instrument to decide matters for which consociational rules apply. From a deliberative democracy perspective, a citizens' assembly - our main focus of interest here - could be initiated. This approach draws on recent real-world 
experience, whereby citizens' assemblies have been held on a range of political issues on which elites have been unable or unwilling to reach agreement. These issues have included the UK's future relationship with the European Union (Renwick 2017), same-sex marriage and abortion in Ireland (Farrell et al. 2019) and electoral reform in the Netherlands and Canada (Fournier et al. 2011; Warren 2008). This approach also draws upon empirical research from deeply divided polities; as Nicole Curato et al. (2017: 34) note, for example, 'deliberation in divided societies can help to bridge the deep conflicts across religious, national, racial, and ethnic lines', under the right conditions. While few mini-publics have been held in Northern Ireland, and none has been commissioned by the devolved government to date, evidence from a deliberative poll on a local education issue and from citizens' assemblies on constitutional matters and on social care for older people indicates that citizens from different community backgrounds are both willing to participate in such bodies and are capable of deliberating in much the same way as elsewhere (Garry et al. 2020a, 2020b; Luskin et al. 2014; Pow and Garry 2019).

In a citizens' assembly, the selection of decision-makers at the input stage (see column 2 of Table 1) would be by random selection (or 'sortition'), leading to an assembly whose composition is essentially a microcosm of society as a whole, with moderate and hard-line citizens in proportion to their prevalence in the wider population. The decision-making process would be characterized by deliberation rather than bargaining: citizens would listen to expert presentations and a range of arguments on the topic before engaging in roundtable discussions. Regarding decision rules, conclusions are typically reached in citizens' assemblies by simple majority, with an absence of group vetoes, which would likely lead to more decisiveness and less gridlock. However, even if citizens' assemblies, through their core design properties, are able to help overcome gridlock in consociational decision-making, it is not clear that such an approach would receive the support of the wider public or political elites. In the absence of widespread public support, the use of citizens' assemblies may undermine, rather than strengthen, democratic stability - adding to political problems instead of helping to solve them (see Easton 1965, 1975). Moreover, in the absence of broad support for the use of citizens' assemblies among elites, such initiatives are unlikely to stand a realistic chance of being implemented in democratic practice. Consequently, if we are to better appreciate the democratic potential - and limitations - of citizens' assemblies on deadlock-inducing issues in deeply divided contexts, we must examine the attitudes of both citizens and those who possess decision-making power.

Given our comparison of the consociational system and citizens' assemblies, we strongly expect more support for citizens' assemblies among the general public than among the political elites. Delegating power to citizens' assemblies whose conclusions they could not predict would involve elected party politicians relinquishing influence, especially so in the extreme case of delegating binding decision-making power. The bottom row of Table 1 specifies further expectations regarding particular sections of the general population who are especially likely to be supportive of citizens' assemblies. Support would probably be high among citizens with politically moderate views given that people with traditionally moderate views within each of the antagonistic ethno-national groups are likely to be proportionally represented in a citizens' assembly rather than under-represented in the consociational 
legislature. Also, support is likely to be high among non-partisans given that power will lie with ordinary citizens rather than parties. Furthermore, citizens who are trusting of out-group members are likely to be particularly supportive of a citizens' assembly given its associated lack of group vetoes. We now confront our expectations with empirical evidence.

\section{Study 1: Do the public support decision-making by mini-publics? Data and method}

In our first study, a representative sample of the Northern Ireland population was asked about a hypothetical citizens' assembly as well as other forms of decision-making: ${ }^{3}$

On some important issues - such as flag display and the issue of welfare reform - the political parties in Northern Ireland find it very hard to agree with each other, and this leads to political crises. When such a crisis happens, there may be a number of ways to try and resolve it. Please tell me to what extent you think each of the following approaches is a good idea or a bad idea.

The different possible approaches presented to respondents correspond to the three broad ways of persevering with the system (through interparty talks chaired either by the British government or an international diplomat, or holding a fresh election), abandoning the system (through direct rule from Westminster), or supplementing the system (with a referendum or a citizens' assembly). To measure perceived legitimacy, respondents were asked the extent to which they thought each form of decision-making would be good or bad as a response to crisis on a five-point Likert scale: 'very good idea', 'good idea', 'neither good nor bad idea', 'bad idea' or 'very bad idea'.

Our specific focus is on people's perceptions of the legitimacy of a citizens' assembly. Compared with the five other options, this form of decision-making is relatively novel and, therefore, unlikely to have been familiar to participants of the survey. Thus, prior to answering the question, respondents were provided with a brief vignette to describe the key features of a citizens' assembly, including the random selection of its members from the general population, their deliberation on the background information, evidence and arguments on both sides of a contentious issue, and the taking of a final decision to be implemented. The text was as follows.

Another possible way of resolving a difficult issue - such as flag display or the issue of welfare reform - would be to get a group of ordinary people to make a decision on it after they have had a chance to consider the evidence and arguments. Here's how it would work ... A representative sample of 500 ordinary citizens in Northern Ireland is selected to consider the issue. These people would be selected in the same way that people are selected to serve on a jury: they are randomly selected. And they would be a cross-section of all of the people in Northern Ireland in terms of age, gender, social class and 
religious and community background. The people on this 'Citizens' Assembly' would be provided with background information about the issue and would be given a presentation of all the main arguments on both sides of the issue. They would be asked to think carefully about the evidence and the different views and would then be asked to vote on the issue. What a majority of these people decided in the vote would be seen as the decision on the issue and would be implemented. What do you think of this possible way of making decisions on difficult issues?

The first two features - random selection and deliberation - are generally common to all citizens' assemblies, at least as they have been constituted in practice (see Farrell et al. 2019); the last - binding decision-making - is more unusual in that a citizens' assembly is usually tasked with reaching an advisory, rather than final, decision. ${ }^{4}$ However, to compare respondents' perceptions of the legitimacy of a citizens' assembly with other modes of binding decision-making, we describe binding, rather than advisory, decision powers for consistency. ${ }^{5}$

To test our expectations regarding individual-level variation in support, we operationalized three independent variables. Ethno-national moderation was measured on a three-point unipolar scale. ${ }^{6}$ Partisan detachment was treated as a dummy variable: respondents who felt distant from all political parties were coded as ' 1 ' while those who felt close to at least one party were coded as ' 0 '.' Similarly, out-group trust was operationalized as a dummy variable: those who trusted members of both of the traditional communities were coded as ' 1 '; those who only trust members of their own community were coded as ' 0 '.

\section{Results}

Compared with other modes of decision-making, Figure 1 shows that people were just as likely to support a citizens' assembly as an institutional response to political crisis. This novel form of decision-making received a mean level of support of $2.63(\mathrm{SD}=1.28)$, the same as the level of support for the 'default' crisis response of holding interparty talks chaired by the British government $(M=2.59$; $\mathrm{SD}=1.11)$ or for a more familiar citizen-based form of decision-making, a referendum $(M=2.51 ; S D=1.20)$. Of the respondents, $62 \%$ thought a citizens' assembly would be a good, or very good, idea as a response to crisis. This evaluation compares to an identical percentage who expressed a positive view towards interparty talks chaired by the British government and the $56 \%$ who thought a referendum was a good solution. The remaining modes of decision-making were less well received: direct rule, an immediate election and holding party talks chaired by an international diplomat all had mean levels of support of less than 2. A majority of respondents thought that each of these responses to crisis would be a mostly bad idea. The difference in the level of support for interparty talks chaired by the British government and by an international diplomat is striking. The particularly weak level of support for the latter may reflect the public's frustration at the breakdown of talks chaired by Richard Haass and Meghan O'Sullivan in 2013, and unionist hostility to engagement in Northern Ireland from non-British sources. 


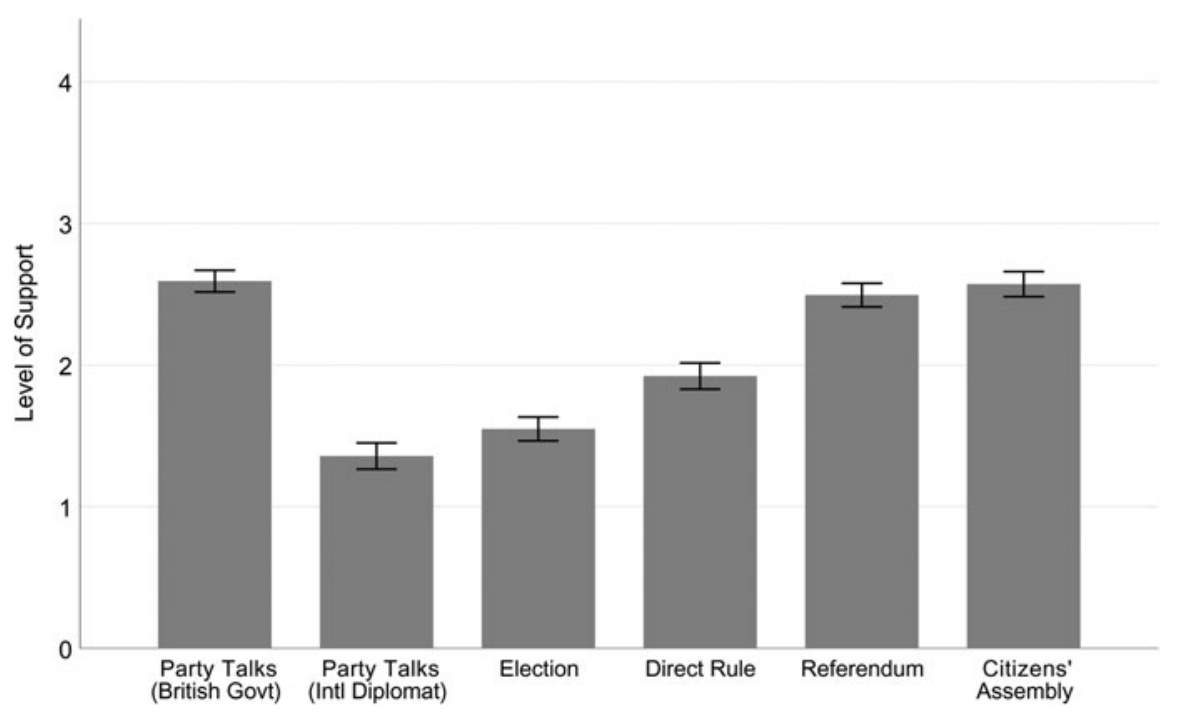

Figure 1. Mean Levels of Support for Different Forms of Decision-Making Note: This figure shows mean levels of support for different types of decision-making as measured on a 0-4 scale, in which 0 = 'a very bad idea' and $4=$ 'a very good idea'. $\mathrm{N}=1,015$.

Table 2 reports an OLS regression predicting support for decision-making by a citizen's assembly on the $0-4$ scale. In line with our expectations, those who hold more ethno-nationally moderate views and those who are more trusting of both communities are significantly more likely to support a citizens' assembly. These relationships hold when controlling for gender, age, religious background and social class. Contrary to our expectations, however, there was no significant association between feeling distant from all political parties and expressing support for a citizens' assembly. ${ }^{9}$ These findings suggest that citizens' assemblies are particularly attractive to individuals who are frustrated with decision-making in consociational political systems, but are not necessarily disengaged from party politics.

While Study 1 has shed light on the level and determinants of public support for citizens' assemblies, it is open to criticism. Citizens may well agree with the general idea of mini-publics making decisions, but if citizens were faced with a decision made by a mini-public with which they disagreed, would they really accept that decision? To address this criticism, and hence more robustly test citizen support, we conducted the following experiment.

\section{Study 2: Public acceptance of mini-public decisions (they disagree with) Data and method}

We focused on a salient and highly contentious ethno-national issue: Irish language policy. Unionist political parties have repeatedly signalled their opposition to an Irish Language Act, viewing it as a threat to Northern Ireland's 'Britishness', whereas Irish nationalist parties are staunchly in favour of such legislation, arguing that it is a necessary demonstration of cross-community respect for the island's 
Table 2. OLS Regression Predicting Support for Decision-Making by Citizens' Assemblies

\begin{tabular}{lll}
\hline & $\mathrm{B}$ & $\mathrm{SE}$ \\
\hline Ethno-national moderation (1-3 scale, least to most moderate) & $0.16^{\star}$ & 0.07 \\
\hline Distant from all parties & 0.02 & 0.12 \\
\hline Trust both communities & $0.22^{\star}$ & 0.09 \\
\hline Women & $0.25^{\star}$ & 0.09 \\
\hline Age & $-0.01^{\star}$ & 0.00 \\
\hline Protestant & - & \\
\hline Catholic & $0.29^{\star}$ & 0.09 \\
\hline Other religion & 0.01 & 0.17 \\
\hline AB social grade & - & \\
\hline C1 social grade & 0.24 & 0.14 \\
\hline C2 social grade & 0.24 & 0.14 \\
\hline DE social grade & $0.51^{*}$ & 0.14 \\
\hline Constant & $1.84^{\star}$ & 0.22 \\
\hline Adjusted $R^{2}$ & 0.06 & \\
\hline
\end{tabular}

Note: ${ }^{\star}=p<0.05$. The dependent variable is the extent to which the respondent thinks citizens' assembly decision-making is a good idea on a 0-4 scale in which 0 ='a very bad idea' and 4 ='a very good idea'. $\mathrm{N}=808$.

indigenous language. Disagreement on this issue figured centrally in the impasse between Northern Ireland's largest parties between 2017 and 2020.

We presented a representative sample of the Northern Ireland population $(\mathrm{N}=$ $2,015)^{10}$ with the following description:

There has been discussion in recent years about whether or not to introduce special rights for people in Northern Ireland who speak Irish. Some people have called for an Irish Language Act, which would be a new law to protect the rights of Irish language speakers and to promote the use of the Irish language in Northern Ireland. Others disagree and are opposed to any special rights for Irish language speakers.

We then asked respondents whether they personally supported or opposed the introduction of an Irish Language Act. They were then presented with a scenario:

Suppose that at some point in the near future the issue of Irish language rights was brought before the Northern Ireland Assembly. After debating it, a majority of MLAs [members of the Legislative Assembly] supported a new law protecting Irish language rights, but it was blocked by the largest unionist party using its power of veto. This led to a worsening of relations among the political parties, creating gridlock in the Assembly and a new political crisis. 
Respondents were randomly assigned to one of six treatments, corresponding with the six different responses to crisis used in Study $1 .{ }^{11}$ They were asked to imagine that a decision has been taken on whether or not to pass an Irish Language Act by one of the six methods of decision-making. Crucially, the decision that participants were presented with was one with which they personally disagreed. In other words, participants who initially indicated their opposition to an Irish Language Act were asked to imagine that a decision had been taken to introduce an Irish Language Act. Conversely, those who initially stated their support for an Irish Language Act were asked to imagine that a decision had been taken not to introduce such an Act. ${ }^{12}$ Participants were asked whether they would accept the decision or not. ${ }^{13}$ By presenting respondents with what James Gibson and Gregory Caldeira (2003:4) call an 'objection precondition', and then measuring their level of acceptance of this personally objectionable decision, we generated a clear test of the perceived legitimacy of different modes of decisionmaking: 'When people approve of a decision, the legitimacy of the decision maker is of little consequence since people are already getting what they want. When the decision is unpopular, its efficacy hinges upon the perceived legitimacy of the decisionmaking process and institution' (Gibson and Caldeira 2003: 4).

Since legitimacy here fundamentally relates to the procedure through which a decision is taken, rather than to its substance (see Tyler 2006), this experiment is intended to measure the effect of specific procedures on decision acceptance, holding constant respondents' instrumental preferences. Essentially, we ask if 'losers' consent' (Nadeau and Blais 1993) is conditional upon how the decision is reached. Figure 2 summarizes the design of the experiment.

\section{Results}

Compared with the observational results reported for Study 1, the experiment found much less variation in people's attitudes towards different modes of decisionmaking. Figure 3 displays the percentage of respondents in each group who said they would accept or not accept the decision on an Irish Language Act. Across all groups, an average of $78 \%$ of respondents said they would accept the personally unfavourable decision, compared with $22 \%$ who would refuse to accept it. From a normative democratic perspective, it is encouraging that a relatively high number of people would still accept a decision taken by some form of democratic instrument, even if they personally oppose the substance of the decision. In the citizens' assembly condition, the acceptance rate was $75 \%$, which was not significantly higher or lower than the acceptance rate in any of the other groups - with one exception. In the referendum condition, $94 \%$ of respondents said they would accept a personally objectionable decision, and this level of decision acceptance is significantly higher than all other decision-making conditions in the experiment.

In an analysis similar to that conducted for Table 2, we conduct a binary logistic regression of participants in the citizens' assembly condition to examine the effect of ethno-national views, partisanship and out-group trust on individual-level support for citizens' assembly decision-making. We find, consistent with Table 2, that having moderate ethno-national views is a statistically significant predictor of decision acceptance. ${ }^{14}$ In percentage terms, as reported in the final column of Table 3 , of those who identify as strongly unionist or nationalist (one in five respondents), 


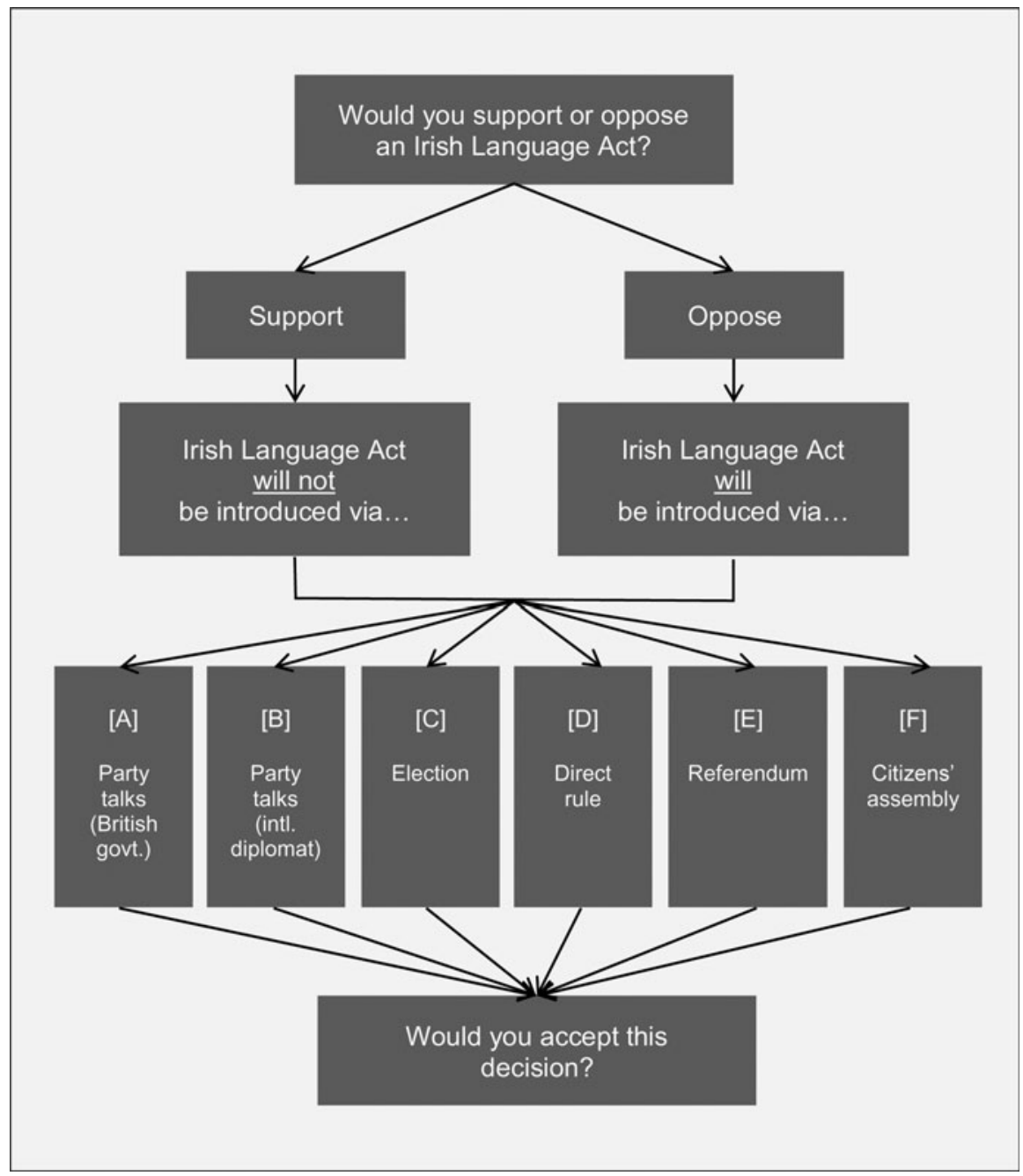

Figure 2. Overview of Experimental Design

just over $40 \%$ said they would accept an unfavourable decision on Irish language policy taken by a citizens' assembly - half the acceptance rate for respondents identifying as moderately nationalist or unionist, or neither. Substantial differences are also found in the other decision-making conditions (columns 1-4, Table 3), with the exception of the referendum condition. In the referendum condition individuals with strong ethno-national views and citizens with moderate ethno-national ideologies were just as likely to accept the decision; acceptance levels exceeded $90 \%$ in each case. ${ }^{15}$ This result may perhaps reflect local experience of referendums as established legitimizing instruments on contested issues: for nationalists they offer the means of achieving a united Ireland; for unionists (largely Eurosceptic) a referendum facilitated the UK's departure from the European Union. But it 


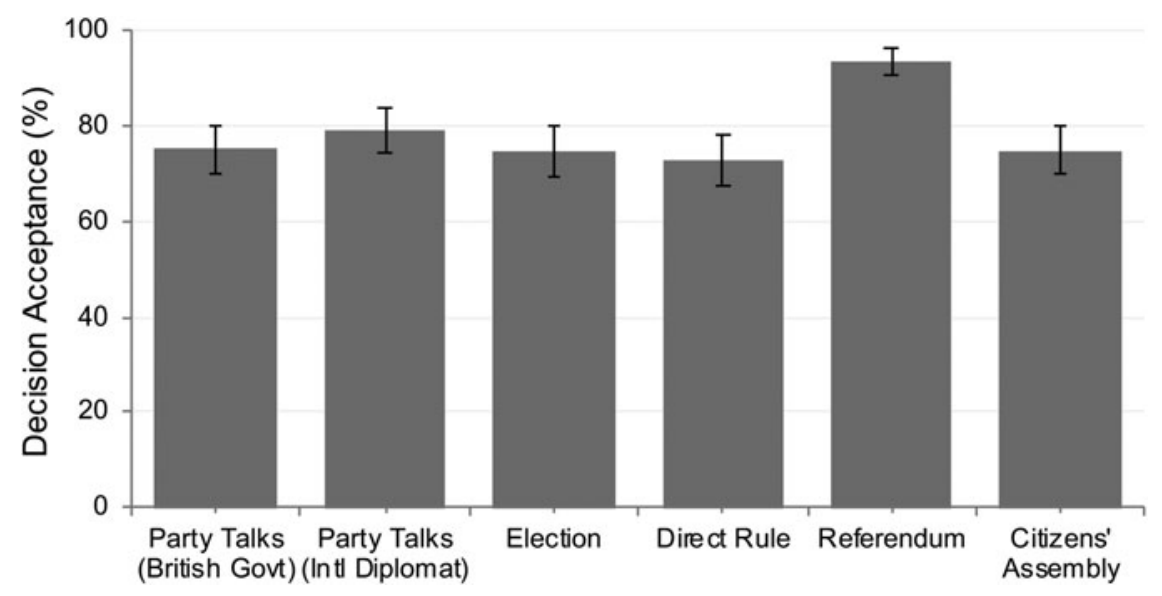

Figure 3. Acceptance of Decisions by Mode of Decision

Note: This figure shows the percentage of people who disagree with the statement that they would find it 'impossible to accept' a decision about the introduction of an Irish Language Act against their own view, depending on the mode of decision-making. $\mathrm{N}=1,728$.

Table 3. Decision Acceptance (\%) by Strength of Ethno-National Ideology

\begin{tabular}{lcccccc}
\hline & $\begin{array}{c}\text { Party } \\
\text { talks } \\
\text { (British } \\
\text { govt) }\end{array}$ & $\begin{array}{c}\text { Party } \\
\text { talks } \\
\text { (intl } \\
\text { diplomat) }\end{array}$ & Election & $\begin{array}{c}\text { Direct } \\
\text { rule }\end{array}$ & Referendum & $\begin{array}{c}\text { Citizens' } \\
\text { assembly }\end{array}$ \\
\hline Moderate & 81 & 82 & 79 & 81 & 94 & 82 \\
\hline Strong & 52 & 58 & 53 & 39 & 92 & 42 \\
\hline Difference & 29 & 24 & 26 & 42 & 2 & 40 \\
\hline N & 282 & 285 & 284 & 275 & 288 & 294 \\
\hline
\end{tabular}

could also reflect the general nature of a referendum: all voters have the opportunity to participate directly, whereas the other decision-making processes, including citizens' assemblies, involve filtering or sampling the population. While only a minority of respondents (19\%) identify with the strongest level of ethno-national ideology, it is these individuals who appear to be particularly sensitive to the 'filtered' nature of representative and deliberative forms of decision-making - and the 'unfiltered' nature of decision-making in referendums.

These findings suggest that not only is there a high level of support for the general idea of a citizens' assembly as a response to political crisis, but that this support is robust. Compared with other more conventional ways of responding to elite-level gridlock, including interparty talks, holding a fresh election, or implementing direct rule from Westminster, a citizens' assembly has the potential to take decisions that are perceived as equally legitimate - even if these decisions run contrary to people's instrumental preferences. ${ }^{16}$

Barring a revolution, a citizens' assembly, with either recommendation or decision-making powers, could only be established by the existing political system, 
so a basic level of support from political parties would be necessary to initiate such powers. In a consociational system initially developed by negotiation and agreement between the rival parties, it would be necessary for any change or amendment to that consociational system to be achieved by agreement between the parties, rather than being imposed. ${ }^{17}$ It is therefore crucial to understand the views of political parties towards the possibility of complementing an existing set of consociational arrangements with a citizens' assembly.

\section{Study 3: Elite views, and how these compare with public views Data and methods}

Of the 108 elected Members of the Legislative Assembly (MLAs) in Northern Ireland, 43 were interviewed, face-to-face, by Ipsos-MORI (November 2015 to January 2016). The sample was calculated by generating an initial random sample and using substitution for non-compliance, ensuring quotas for gender, ethnonational ideology (unionist, nationalist or neither) and geography. Representatives from all five of Northern Ireland's main political parties were interviewed. A battery of questions was asked that largely replicated the questions in Study 1. We can therefore compare how the elite and the public think about the potential role of mini-publics. Also included was an open-ended question that asked MLAs what they saw as the advantages and disadvantages of having a decision-making minipublic. Responses were audio-taped and transcribed.

\section{Results}

Figure 4 revisits the questions examined in Study 1 and reports the difference between elite and public agreement with particular institutional responses to political crises. In general, MLAs were less positive about all options apart from talks chaired by an international diplomat. Some of these differences are large and, crucially, the biggest difference between the two groups relates to views on the idea of decisions being made by a citizens' assembly. Just 17\% of MLAs regarded this as a good way to make decisions (a difference of -48 compared with the public).

Further light can be shed on the negative disposition of the MLAs by investigating their responses to the open-ended survey question about the disadvantages of a decision-making mini-public. By far the dominant theme was that a decisionmaking citizens' assembly would be undemocratic: it would undermine the role of elected representatives and would simply duplicate the work they already carried out. As several different MLAs commented:

It will keep some of the chattering classes happy, but it's an unelected body and it's absolute nonsense. (DUP MLA, id18)

They are considering big issues, and because the decisions are binding it's not democratic. You could have controversial decisions being implemented without any democratic basis for it at all. It would undermine the Assembly and people in their right to vote. (Sinn Féin MLA, id10) 


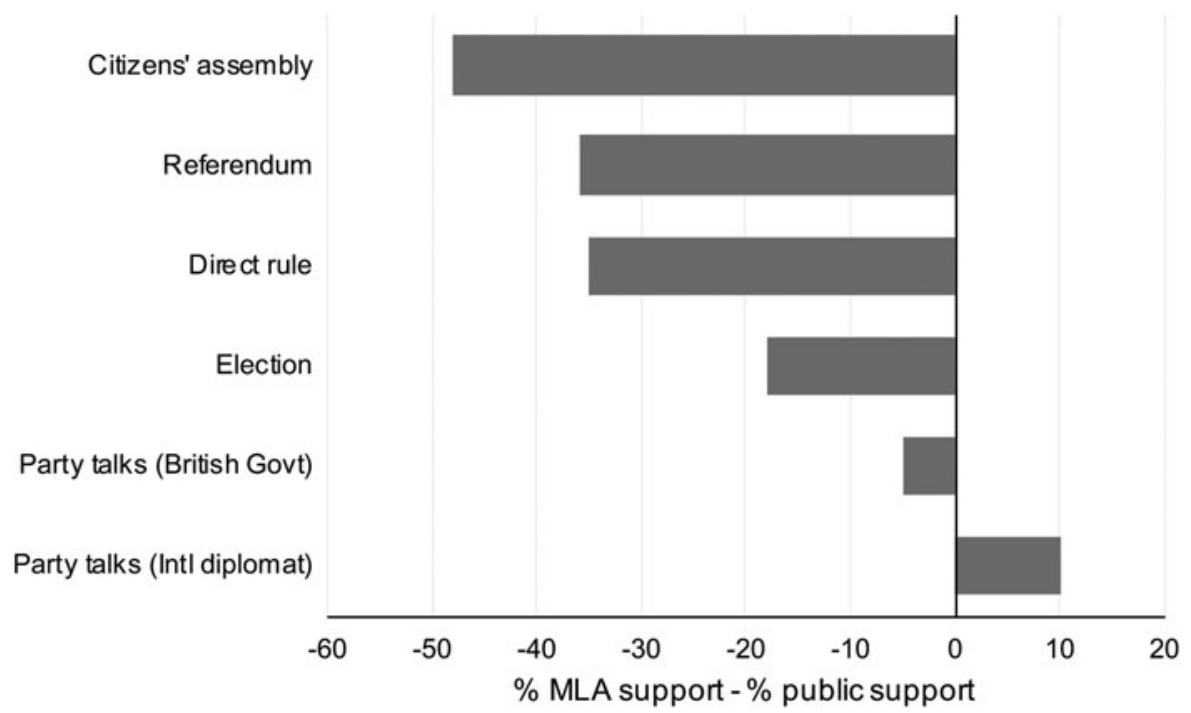

Figure 4. Difference Between MLA and Public Support for Different Resolution Approaches (MLA \% minus public \%)

Note: This figure shows the difference between the percentage of MLAs who support a particular crisis resolution method and the percentage of the public who support a particular crisis resolution method.

We already have an elected government here. It's important for people to have their views heard, but they are already given this opportunity. (Alliance MLA, id39)

Undemocratic: it takes the decision-making out of the hands of the elected representatives. People have their choice with the ballot box and that's when they have their say. If someone wants to be an elected representative then they should join a political party or stand as an individual candidate. The mandate needs to be respected ... I see it as a way of trying to get around the democratic process. It may not be representative of what the majority of people want. (DUP, MLA id17)

These views represent foundational criticism of citizens' assemblies as undemocratic. They suggest a very strong connection in the minds of many MLAs between the general idea of democracy and the dominant way of operationalizing the idea of democracy $($ democracy $=$ representative democracy $=$ competitive elections $)$. These findings, however, do not mean that there was unconditional MLA antipathy to mini-publics. The results reported in Table 4 suggest much less disagreement between the public and the elite if the role of the citizens' assembly was defined to 'make a recommendation to be considered by politicians' (61\% of both groups opted for this option) rather than one in which their conclusions would be binding ('make the final decision') or 'not have any role at all in policy-making'. Consistent with these data, MLA respondents said in the open-ended questions that it could be advantageous to 'hear the voice of the people' (DUP MLA, id40), and that there 
Table 4. Attitudes Towards Citizen Assemblies: Elite and Public

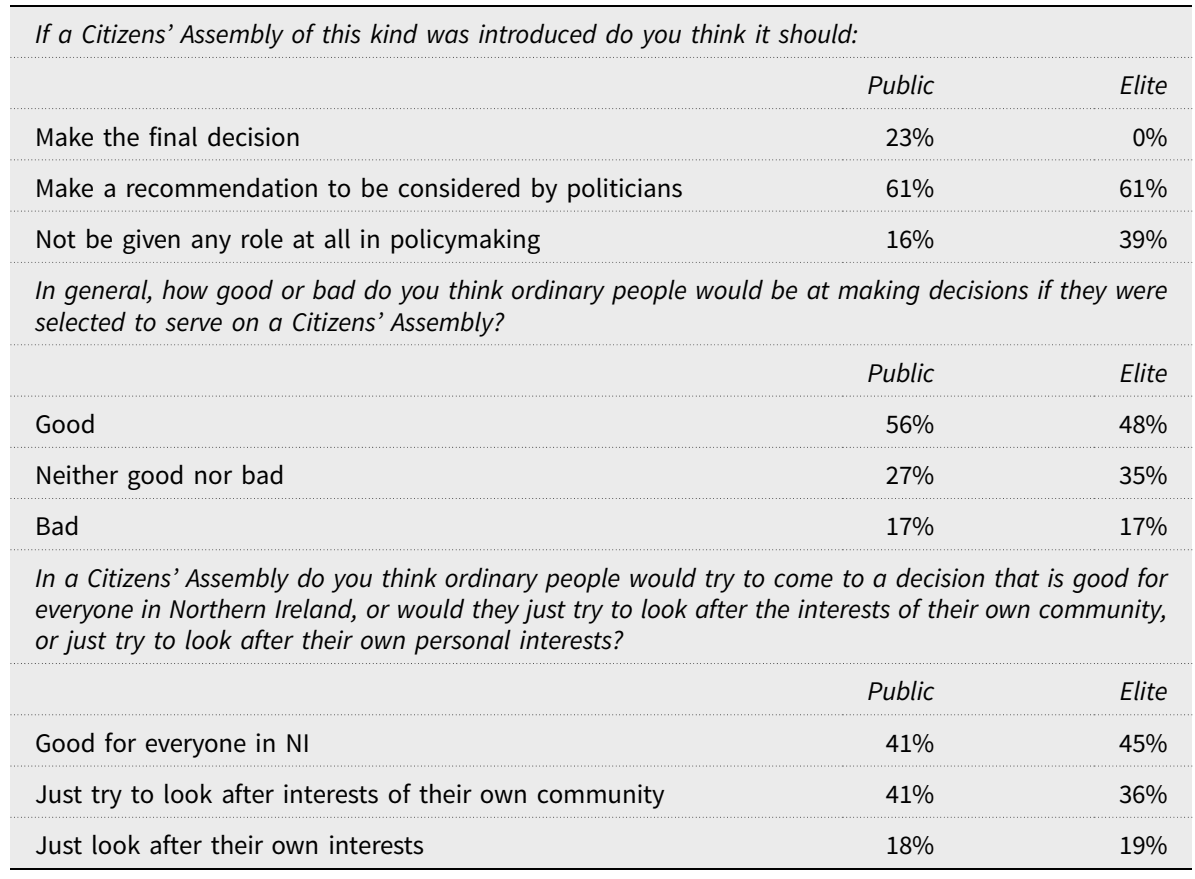

Note: The public figures come from a representative sample of the Northern Irish population $(\mathrm{N}=1,015)$ and the elite figures come from a representative sample of MLAs $(N=43)$.

could be 'merit' in a citizens' assembly having 'a consultative role' (Sinn Féin MLA, id12). Others similarly stated:

Might be a good way to get different views. If this was published it could provide useful recommendations. (DUP MLA, id4)

Could be used as a consultative body rather than the final decision-makers. It would give you a general view of the public. (Alliance MLA, id5)

Both elite and public respondents evaluated the ability of ordinary citizens to engage in a mini-public positively. Just $17 \%$ of each group (MLAs and the public) believed that 'ordinary people' would be bad 'at making decisions if they were selected to serve on a citizens' assembly' (Table 4). Nonetheless, there were clearly some concerns raised by MLAs in the open-ended responses:

You can't bring ordinary people in cold that have no experience of these matters and expect them to make decisions in a matter of days or weeks. (DUP MLA, id18)

They wouldn't be able to dig down deep into the bones of a subject and debate it thoroughly. (Sinn Féin MLA, id26) 
Lack of experience and willingness to serve. Might not have any interest in politics, whereas elected politicians tend to have a genuine interest in politics. (Ulster Unionist Party (UUP) MLA, id36)

The views of the public and elite are very similar in terms of how they perceive the motivation of potential members of a citizens' assembly. Less than a fifth of both groups believe citizens would just be looking after their own personal interests. Over two-fifths of both citizens and elites, as reported in Table 4, regarded citizens as likely to seek a decision for 'the good of everyone in Northern Ireland'. These responses resonate with several of the comments made by MLAs in the open-ended question on the advantages of a decision-making mini-public to address divisive gridlocked issues.

Help to get rid of some of the road blocks experienced at Stormont [Northern Ireland's seat of devolved government]. It would also entail people making decisions that are not based on religious convictions. (DUP MLA, id34)

People wouldn't be left in their trenches. They wouldn't have the baggage of traditions of their political party. Might find some fresh thinking. (UUP MLA, id36)

It would break political deadlock on contentious issues and would be an alternative to continued political deadlock, indecision and political paralysis. (SDLP MLA, id3)

I would imagine it would result in decisions being made so that we could all move forward. (DUP MLA, id27)

\section{Concluding discussion}

Citizens' assemblies have been established internationally as responses to particular circumstances in which elected politicians are unable, or unwilling, to resolve a contentious issue (Contiades and Fotiadou 2017; Reuchamps and Suiter 2016; Smith 2009; Warren and Pearse 2008). In the specific context of a deeply divided society, it is typically assumed that it is political elites, rather than ordinary citizens, who are in the best position to reach decisions on contested issues that can be accepted as legitimate (Nordlinger 1972). However, in this study, we find considerable support from the public, not just for the idea of a decision-making citizens' assembly but also for accepting from a citizens' assembly policy outcomes with which they disagree. These results are, however, significantly tempered by the finding that citizens with the strongest ideological views are less likely than moderates to be in favour of citizens' assemblies, and the former may be more politically important than the latter.

As for party elites, we find - unsurprisingly - that they are hostile to citizens' assemblies with decision-making powers, and our qualitative findings shed light on the core source of the hostility. Representative politicians have a deeply held view of democracy as election-based; for them a decision-making body based on random selection rather than election is undemocratic. Advocates of decision- 
making citizens' assemblies face the significant challenge of credibly persuading the elite that their suggestion is actually democratic. However, elected elites are supportive of the more modest use of citizens' assemblies as bodies that make recommendations for consideration by politicians, in line with previous findings from Christoph Niessen (2019), and corresponding with the standard remit of citizens' assemblies internationally as vehicles for making recommendations that are then assessed either by referendum or elected legislators, or both.

Recent political developments in Northern Ireland have increased the likelihood of official, government-established citizens' assemblies actually being established. A crisis in the consociational power-sharing executive resulted in the collapse of devolved government in January 2017, and the triggering of a snap Assembly election. The outcome did little to resolve the differences between the main political parties and multiple rounds of interparty talks chaired by the British government failed to revive the executive. However, in January 2020 a further round of talks succeeded, and the resulting agreed deal ('New Decade, New Approach') included a provision for establishing a panel that 'will be invited to propose the most appropriate model of engagement for specific issues, including one Citizens' Assembly a year. The issues will be identified by the Executive' (Northern Ireland Office 2020). While the wording may be somewhat ambiguous, it formally indicates that citizens' assemblies will be considered. If they are initiated, our findings in this article suggest that a high degree of perceived legitimacy from the public, and a reasonable degree from the elites, are likely. Our findings also emphasize that two significant caveats are necessary. Support among the public is lower than that relating to holding a referendum, and arguably the most important actors in a deeply divided place, ideologically hard-line citizens, are more lukewarm in their support for citizens' assemblies than are political moderates.

Our findings have import more generally for post-conflict democratic design. Consociational theory provides a powerful intellectual foundation from which democratic institutions may be designed to meet the needs of deeply divided places. But specific arrangements can be far from perfect in practice. Future consociations, we suggest, should be negotiated to anticipate the potential gridlock problems associated with this kind of system and plan accordingly. Incorporating some form of supplementary citizen-based decision-making, or recommendation-making, may be considered in institutional arrangements from the outset. One option would be to formally outline a role for a citizens' assembly in the specific event that a consociational power-sharing administration encounters destabilizing gridlock on a specific policy issue. Another option, more applicable to existing consociations, would be to allow citizens' assemblies to consider if and how institutional arrangements should be revised.

Supplementary material. To see the supplementary material for this article, please go to https://oi.org/ 10.1017/gov.2021.4.

Acknowledgements. This work was supported by the Economic and Social Research Council (grant numbers ES/M000257/1, ES/L005808/1).

\section{Notes}

1 Consociation is one type of power-sharing and both power-sharing and consociation come in many varieties (see McGarry and O'Leary 2016; O’Leary 2013). 
2 In the Northern Ireland case, multiparty talks chaired by American diplomat Richard Haass and Harvard University academic Professor Meghan O'Sullivan, for example, lasted from September to December 2013 but failed to result in a multiparty agreement on the regulation of flags and parading, and dealing with the legacy of the past. Other talks between political elites have been more successful, resulting in the Hillsborough Agreement (2010), the Stormont House Agreement (2014), the Fresh Start Agreement (2015) and the 'New Decade, New Approach' deal (2020).

3 Face-to-face in-home interviews were conducted by Ipsos-MORI with 1,015 participants in October 2015. Randomized geographic sampling points were used, with quotas generated for small area units based on census data. The resulting sample is representative of the general Northern Ireland population in terms of basic demographic variables (geography, gender, age, social class) as well as ethno-national background. The citizens' assembly was hypothetical for the simple reason that a real-world citizens' assembly with legally binding decision-making powers has not been conducted.

4 Retrospectively we regret not including in the vignette brief descriptions of arguments in favour and arguments against citizens' assemblies. Future research could explore people's general level of awareness of citizens' assemblies, as well as how people's attitudes are shaped by specific design features, normative arguments and empirical experience.

5 See Bedock and Pilet (2020a, 2020b) on public attitudes to citizens' assemblies being the main vehicle for policymaking. We also asked about the more conventional recommendation-making powers - see below. 6 Respondents were asked: 'Would you say that you are ... very strongly unionist, fairly strongly unionist, neither unionist nor nationalist, fairly strongly nationalist, or very strongly nationalist?' Those identifying as very strongly unionist or nationalist are coded ' 0 ', those identifying as fairly strongly unionist or nationalist are coded ' 1 ', and those identifying as neither unionist nor nationalist are coded ' 2 '.

7 Respondents were asked on a five-point scale the extent to which they felt close to or distant from each of the five main political parties: the Democratic Unionist Party (DUP), the Ulster Unionist Party (UUP), the Social Democratic and Labour Party (SDLP), Sinn Féin, and the Alliance Party.

8 Respondents were asked (on a five-point scale) the extent to which they trusted 'people from a Catholic/ nationalist community background' and 'people from a Protestant/unionist community background'. People who gave a positive response for both items were coded as trusting of both communities.

9 Ethno-national moderation, feeling distant from all political parties and trusting both communities do not significantly predict support for any other mode of decision-making, but ethno-national moderates are more likely to support interparty talks chaired by an international diplomat.

10 In February-April 2017 face-to-face in-home interviews were conducted by Ipsos-MORI with 2,015 participants, using the same methodology as Study 1 to ensure a representative sample of the whole population. A larger number of respondents than in Study 1 was used because of the number of experimental conditions employed.

11 Randomization checks on the data assessed whether experimental groups varied by demographics (gender and age) or attitudinal and political variables (position on an Irish Language Act and ethno-national identity). No statistically significant differences emerged.

12 Respondents who initially responded 'don't know' regarding their preference on an Irish Language Act were probed further: 'If you had to choose, would you be slightly more inclined to support special rights for Irish language speakers, or slightly more inclined to oppose special rights for Irish language speakers?' They could still respond 'really don't know'.

13 The response categories were: (1) 'I would find this almost impossible to accept, (2) 'I would not like it but could live with it if I had to' and (3) 'I would happily accept the decision'. We combine the last two categories to capture all respondents who indicate some degree of decision acceptance.

14 The other two factors were not statistically significant: see the Online Appendix, Table 1 for full results and details.

15 In a logistic regression analysis we found that being in the referendum rather than citizens' assembly experimental condition statistically significantly $(\mathrm{p}=0.02)$ moderated the impact of ethno-national views on decision acceptance (results in the Online Appendix, Table 2).

16 Our findings are necessarily limited because we have only experimentally focused on one issue - the Irish Language Act - at one point in time. However, given that it has been a highly salient and divisive issue, it is reasonable to expect similar findings for other similarly highly salient and divisive issues.

17 For the argument applied to Bosnia and Northern Ireland see McCrudden and O'Leary (2013). 


\section{References}

Bedock C and Pilet J (2020a) Who Supports Citizens Selected by Lot to be the Main Policymakers? A Study of French Citizens. Government and Opposition: An International Journal of Comparative Politics, published early online, April. https://doi.org/10.1017/gov.2020.1.

Bedock C and Pilet J (2020b) Enraged, Engaged, or Both? A Study of the Determinants of Support for Consultative vs. Binding Mini-Publics. Representation, published early online, June. https://oi.org/10. 1080/00344893.2020.1778511.

Carson L and Schecter D (2019) Why do Politicians Love or Hate the Idea of Citizens' Juries? New Democracy, 26 November. www.newdemocracy.com.au/wp-content/uploads/2019/12/RD-Note-Politiciansand-Citizens-Juries.pdf.

Contiades X and Fotiadou A (eds) (2017) Participatory Constitutional Change: The People as Amenders of the Constitution. London: Routledge.

Curato N et al. (2017) Twelve Key Findings in Deliberative Democracy Research. Daedalus 146(3), 28-38. https:/doi.org/10.1162/DAED_a_00444.

Dryzek JS et al. (2019) The Crisis of Democracy and the Science of Deliberation. Science 363(6432), 11441146. https://doi.org/10.1126/science.aaw2694.

Easton D (1965) A Framework for Political Analysis. Englewood Cliffs, NJ: Prentice-Hall.

Easton D (1975) A Re-Assessment of the Concept of Political Support. British Journal of Political Science 5 (4), 435-457.

Farrell DM, Suiter J and Harris C (2019) 'Systematizing' Constitutional Deliberation: The 2016-18 Citizens' Assembly in Ireland. Irish Political Studies 34(1), 113-123. https://doi.org/10.1080/07907184. 2018.1534832.

Fishkin JS (2009) When the People Speak: Deliberative Democracy and Public Consultation. Oxford: Oxford University Press.

Fournier P et al. (2011) When Citizens Decide: Lessons from Citizen Assemblies on Electoral Reform. Oxford: Oxford University Press.

Garry J et al. (2020a) Public Attitudes to Different Possible Models of a United Ireland: Evidence from a Citizens' Assembly in Northern Ireland. Irish Political Studies 35, 3. https://doi.org/10.1080/07907184. 2020.1816379.

Garry J et al. (2020b) The Future of Northern Ireland: Border Anxieties and Support for Irish Reunification under Varieties of UKEXIT. Regional Studies, published early online, June. https:/doi. org/10.1080/00343404.2020.1759796.

Gastil J and Wright EO (2019) Legislature by Lot: Transformative Designs for Deliberative Governance. London: Verso Books.

Gibson JL and Caldeira GA (2003) Defenders of Democracy? Legitimacy, Popular Acceptance, and the South African Constitutional Court. Journal of Politics 65(1), 1-30. https://doi.org/10.1111/1468-2508. t01-1-00001.

Hayward K (2014) Deliberative Democracy in Northern Ireland: Opportunities and Challenges for Consensus in a Consociational System. In Ugarriza JE and Caluwaerts D (eds), Democratic Deliberation in Deeply Divided Societies: From Conflict to Common Ground. Basingstoke: Palgrave Macmillan, pp. 11-34.

Hennig B (2017) The End of Politicians: Time for a Real Democracy. London: Unbound.

Johnson C and Gastil J (2015) Variations of Institutional Design of Empowered Deliberation. Journal of Public Deliberation 11(1), 1-32. http://doi.org/10.16997/jdd.219.

Luskin RC et al. (2014) Deliberating Across Deep Divides. Political Studies 62(1), 116-135. https://doi.org/ 10.1111/j.1467-9248.2012.01005.x.

Mackenzie M and Warren ME (2012) Two Trust-Based Uses of Minipublics in Democratic Systems. In Parkinson J and Mansbridge J (eds), Deliberative Systems: Deliberative Democracy at the Large Scale. Cambridge: Cambridge University Press, pp. 95-124.

Mansbridge J (2007) 'Deliberative Democracy' or 'Democratic Deliberation'? In Rosenberg S (ed.), Can the People Govern? Deliberation, Participation and Democracy. New York: Palgrave Macmillan, pp. 251-271.

McCrudden C and O'Leary B (2013) Courts and Consociations: Human Rights versus Power-Sharing. Oxford: Oxford University Press.

McCulloch A (2014) Power-Sharing and Political Stability in Deeply Divided Societies. Abingdon: Routledge. 
McGarry J and O'Leary B (2009) Power Shared After the Deaths of Thousands. In Taylor R (ed.), Consociational Theory: McGarry and O'Leary and the Northern Ireland Conflict. London: Routledge, pp. 15-84.

McGarry J and O'Leary B (2016) Power-Sharing Executives: Consociational and Centripetal Formulae and the Case of Northern Ireland. Ethnopolitics 15(5), 497-519. https://doi.org/10.1080/17449057.2015. 1088231.

Mitchell P and Evans G (2009) Ethnic Party Competition and the Dynamics of Power-Sharing in Northern Ireland. In Taylor R (ed.), Consociational Theory: McGarry and O'Leary and the Northern Ireland Conflict. London: Routledge, pp. 146-164.

Mitchell P, Evans G and O'Leary B (2009) Extremist Outbidding in Ethnic Party Systems is Not Inevitable: Tribune Parties in Northern Ireland. Political Studies 57(2), 397-421. https://doi.org/10.1111/j.14679248.2008.00769.x.

Nadeau R and Blais A (1993) The Effect of Participation on Losers' Consent. British Journal of Political Science 23, 553-563. https://doi.org/10.1017/S0007123400006736.

Niessen C (2019) When Citizen Deliberation Enters Real Politics: Politicians and Stakeholders Envision the Place of a Deliberative Mini-Public in Political Decision-Making. Policy Sciences 52, 481-503. https:/doi. org/10.1007/s11077-018-09346-8.

Nordlinger E.A. (1972) Conflict Regulation in Divided Societies. Cambridge, MA: Harvard University Press.

Northern Ireland Office (2020) New Decade, New Approach. Belfast: Northern Ireland Office.

O'Leary B (2013) Power Sharing in Deeply Divided Places: An Advocate's Introduction. In McEvoy J and O'Leary B (eds), Power-Sharing in Deeply Divided Places. Philadelphia: University of Pennsylvania Press, pp. 1-66.

O'Leary B (2020) A Treatise on Northern Ireland: Consociation and Confederation. Vol. 3. Oxford: Oxford University Press.

Pow J and Garry J (2019) Citizens' Assembly for Northern Ireland: Summary of Participant Evaluations. Belfast: Involve. www.involve.org.uk/sites/default/files/field/attachemnt/Citizens\%27\%20Assembly\% 20for\%20Northern\%20Ireland\%20-\%20Summary\%20of\%20participant\%20evaluations.pdf.

Renwick A (2017) Citizens' Assemblies: A Better Way of Doing Democracy? Political Insight 8(3), 24-27.

Reuchamps M and Suiter J (eds) (2016) Constitutional Deliberative Democracy in Europe. Colchester: ECPR Press.

Rojon S, Rijken AJ and Klandermans B (2019) A Survey Experiment on Citizens' Preferences for 'Votecentric' vs. 'Talk-centric' Democratic Innovations with Advisory vs. Binding Outcomes. Politics and Governance 7(2), 213-226. http://dx.doi.org/10.17645/pag.v7i2.1900.

Smith G (2009) Democratic Innovations: Designing Institutions for Citizen Participation. Cambridge: Cambridge University Press.

Steiner J (2012) The Foundations of Deliberative Democracy. Cambridge: Cambridge University Press.

Tyler TR (2006) Psychological Perspectives on Legitimacy and Legitimation. Annual Review of Psychology 57, 375-400. https://doi.org/10.1146/annurev.psych.57.102904.190038.

Vandamme P-É et al. (2018) Intercameral Relations in a Bicameral Elected and Sortition Legislature. Politics \& Society 46(3), 381-400. https://doi.org/10.1177/0032329218789890.

Van Reybrouck D (2014) Contre les Élections. Brussels: Actes Sud Editions.

Warren ME (2008) Citizen Representatives. In Warren ME and Pearse H (eds), Designing Deliberative Democracy: The British Columbia Citizens' Assembly. Cambridge: Cambridge University Press, pp. 50-69.

Warren ME and Pearse H (eds) (2008) Designing Deliberative Democracy: The British Columbia Citizens' Assembly. Cambridge: Cambridge University Press.

Cite this article: Garry J, Pow J, Coakley J, Farrell D, O'Leary B, Tilley J (2022). The Perception of the Legitimacy of Citizens' Assemblies in Deeply Divided Places? Evidence of Public and Elite Opinion from Consociational Northern Ireland. Government and Opposition: An International Journal of Comparative Politics 57, 532-551. https://doi.org/10.1017/gov.2021.4 